\title{
EVALUATION OF CORIANDER (Coriandrum sativum L.) GENOTYPES FOR FOLIAGE YIELD AND ITS ATTRIBUTES
}

\author{
M. MONiRUZZAMAN ${ }^{1}$, M. M. RAHMAN ${ }^{2}$, M. M. HOSSAIN ${ }^{3}$ \\ A. J. M. SIRAJUL KARIM ${ }^{4}$ AND Q. A. KHALIQ ${ }^{5}$
}

Keywords: Coriander, Coriandrum sativum L., foliage yield, aromatic leaves, BSMRAU.

Coriander (Coriandrum sativum L.), an important spice crop known as 'Dhonia' in Bangla is normally cultivated in winter season in Bangladesh. It is grown throughout the country for the leaves as well as seeds (Islam et al., 2004). Seeds of the crop are used as spice while its tender green leaves are used as culinary herb. It has found to be a remunerative crop. The entire plant of young coriander is used as appetizer in preparing fresh chutneys and sauces. Fresh leaves are used to flavour food, curries, soups, fish sauce, cream sauce for chicken, etc. (Janardhanan and Thoppil, 2004; Tiwary and Agarwal, 2004). At present the cultivation of coriander has been increased for leaf purpose. But there is no recognized commercial variety except BARI Dhonia-1, which is used for seed production. Still there has not been developed any variety suitable for leaf (foliage) production. Now, it is necessary to develop more suitable varieties for foliage production to fulfill the present increasing demand of this spice crop for leaf.

Germplasm collection with good variability for the desirable characters is the basic requirement of any crop improvement program (Singahania et al., 2006). In addition crop improvement is primarily based on extensive evaluation of germplasm (Ghafoor et al., 2001). As coriander is an important spice crop, it needs a great deal of critical evaluation of the available types for selection of the improved types with high yield potential. Selection of better plant type has important value to the breeder for further improvement and development of the crop. Therefore, the present investigation was undertaken to observe the performances of coriander genotypes and select the promising genotype (s) for higher foliage yield.

The experiment was conducted at the Horticulture Field Laboratory of Bangabandhu Sheikh Mujibur Rahman Agricultural University (BSMRAU), Gazipur during December 2007 to April 2008. The $\mathrm{pH}$ value of the soil was 5.9. Fourteen genotypes of coriander as treatments were included in this study. The genotypes were collected from different parts of Bangladesh and some from reputed seed stores of the country. The collected genotypes were recorded as accession no. CS001 to CS014. The genotype CS014 was the BARI Dhonia-1.

\footnotetext{
${ }^{1}$ Senior Scientific Officer, HRC, Bangladesh Agricultural Research Institute (BARI),

${ }^{2}$ Professor, Dept. of Horticulture, Bangabandhu Sheikh Mujibur Rahman Agricultural University (BSMRAU), Salna, Gazipur-1706, ${ }^{3}$ Professor, Dept. of Horticulture., BSMRAU, Salna, Gazipur-1706, ${ }^{4}$ Professor, Dept. of Soil Science, BSMRAU, Salna, Gazipur-1706, ${ }^{5}$ Professor, Dept. of Agronomy, BSMRAU, Salna, Gazipur-1706, Bangladesh.
} 
The experiment was laid out in a randomized complete block (RCB) design with three replications. The plot size was $3 \mathrm{mx} 1 \mathrm{~m}$. Fertilizers were applied @ $80 \mathrm{~kg} \mathrm{~N}, 35 \mathrm{~kg} \mathrm{P}, 60 \mathrm{~kg} \mathrm{~K}$ and $20 \mathrm{~kg} \mathrm{~S}$ and 10 ton cowdung per hectare (Anon., 2001). The entire amount of cowdung, phosphorus from TSP, and potassium from MP, sulphur from gypsum with one-half of nitrogen from urea were applied during final land preparation. The rest of the nitrogen was topdressed at 30 days after sowing. The seeds (fruits) were rubbed for separating the two mericarps (seeds) which were soaked in water for 24 hours to enhance germination. Seeds were also treated with Bavistin at $2 \mathrm{~g}$ per $\mathrm{kg}$ of seeds prior to sowing in raised seed bed at $20 \mathrm{~cm}$ apart rows continuously by hand @ $30 \mathrm{~kg} / \mathrm{h}$. Seeds were mixed with some loose soil (about four to five times of weight of seeds) to allow uniform sowing in rows and were covered with good pulverized soil just after sowing with gently pressed by hands. The sowing was done on 5 December 2007. Light watering was done to supply sufficient moisture needed for quick germination. Weeding and thinning was not done. For good germination, water was given to the plots at every three days by water can with fine mashed nozzle till germination. Later on, two irrigations were applied at 20 and 25 days after sowing. Harvesting of green foliage was done before bolting by cutting just beneath the soil with root intact after 30-40 days of sowing depending upon genotypes. Data was collected from the inner rows of each plot to avoid the border effect. In each unit plot, 10 plants were selected randomly for recording data on days to $50 \%$ germination, days to green plant harvest, plant height, leaves per plant, plant weight, no. of green plants $/ \mathrm{m}^{2}$, and foliage yield ( $\left.\mathrm{kg} / \mathrm{plot}\right)$. Then the plot yield was converted to hectare yield (t/ha). Stem and leaf colour were also recorded by close observation. Tender leaf of young seedlings was twisted by fingers and smell was tested by 10 persons for characterization into strong, moderate and mild. The collected data were properly analyzed statistically by MSTAT program. The mean comparison was done following the Duncan's Multiple Range Test (DMRT) at 5\% level of probability.

The colour of the stems of 14 coriander genotypes was classified as light green, light violet, deep violet, and greenish violet (Table 1). The genotypes, CS003, CS004, CS005, CS007, CS010, CS013, and CS014 produced stems with light green colour, but CS006, CS009, CS011 and CS012 genotypes had light violet colour stem, whereas the stems of CS001 and CS002 genotypes had deep violet colour and the remaining CS008 genotype produced stem with greenish violet colour. Variation of stem colour was reported by Weiss (2002) who classified the stem of coriander as light green, light green with violet tinge and violet. This result is in partial agreement with Rahman (2000) who classified the leaves of coriander genotypes as light green and deep green. The tender leaves of 30 days old seedling of eleven genotypes viz. CS004, CS005, CS006, CS007, CS008, CS009, CS010, CS011, CS012, CS013 and CS014 had strong aroma while two genotypes (CS002 and CS003) had mild aroma (Table 1). The rest (CS001) produced moderate aromatic leaves. 
Table 1. Stem colour, leaf colour, leaf aroma and foliage yield attributes and yield of fourteen coriander genotypes.

\begin{tabular}{|c|c|c|c|c|c|c|c|c|c|c|}
\hline Genotypes & Stem colour & $\begin{array}{l}\text { Leaf } \\
\text { colour }\end{array}$ & $\begin{array}{c}\text { Leaf } \\
\text { aroma } \\
(1-3 \\
\text { scale })\end{array}$ & $\begin{array}{c}\text { Days to } \\
\text { green } \\
\text { plant } \\
\text { harvest }\end{array}$ & $\begin{array}{c}\text { Plant } \\
\text { height }(\mathrm{cm})\end{array}$ & $\begin{array}{c}\text { Leaves/plant } \\
\text { (no.) }\end{array}$ & $\begin{array}{c}\text { Single } \\
\text { plant wt } \\
\text { (g) }\end{array}$ & $\begin{array}{c}\text { Green } \\
\text { plant } / \mathrm{m}^{2} \\
\text { (no.) }\end{array}$ & $\begin{array}{c}\text { Green } \\
\text { plant wt } \\
\left(\mathrm{g} / \mathrm{m}^{2}\right)\end{array}$ & $\begin{array}{c}\text { Foliage } \\
\text { yield } \\
\text { (t/ha) }\end{array}$ \\
\hline CS 001 & Deep violet & $\begin{array}{l}\text { Deep } \\
\text { green }\end{array}$ & 2 & $46.00 \mathrm{~b}$ & $15.94 \mathrm{~b}$ & $6.70 \mathrm{~b}$ & $2.22 b$ & $293.9 b$ & $665.9 b$ & $6.47 \mathrm{~b}$ \\
\hline CS 002 & Deep violet & Green & 3 & $46.00 \mathrm{~b}$ & $15.36 \mathrm{~b}$ & $6.35 b$ & $2.39 \mathrm{~b}$ & 313.7ab & $670.3 b$ & $6.69 \mathrm{~b}$ \\
\hline CS 003 & Light green & Green & 3 & $55.33 a$ & $18.96 a$ & $8.10 \mathrm{a}$ & 3.81a & $264.0 \mathrm{~b}$ & $972.2 \mathrm{a}$ & $9.85 a$ \\
\hline CS 004 & Light green & Green & 1 & $33.67 \mathrm{e}$ & 13.21bcd & $5.05 c$ & $1.21 \mathrm{e}$ & $279.7 b$ & $275.1 f$ & $2.75 \mathrm{~h}$ \\
\hline CS 005 & Light green & $\begin{array}{l}\text { Light } \\
\text { green }\end{array}$ & 1 & 34.33de & $11.25 \mathrm{~d}$ & $5.35 c$ & $1.37 d$ & $267.0 \mathrm{~b}$ & $327.8 f$ & 3.12gh \\
\hline CS 006 & Light green & Green & 1 & 34.67cde & 12.11bcd & $5.45 c$ & 1.49cde & 323.0ab & 416.2de & $3.95 f$ \\
\hline CS 007 & Light green & Green & 1 & 35.00cde & 14.30bcd & $5.10 \mathrm{c}$ & $1.82 \mathrm{c}$ & 321.3ab & 467.8cd & $4.90 \mathrm{~d}$ \\
\hline CS 008 & $\begin{array}{l}\text { Greenish } \\
\text { violet }\end{array}$ & Green & 1 & $36.00 \mathrm{c}$ & $15.26 \mathrm{~b}$ & $5.40 \mathrm{c}$ & $1.80 \mathrm{c}$ & $316.0 \mathrm{ab}$ & $515.8 \mathrm{c}$ & 5.08cd \\
\hline CS 009 & Light violet & $\begin{array}{l}\text { Light } \\
\text { green }\end{array}$ & 1 & $35.67 \mathrm{~cd}$ & 11.70cd & $5.05 c$ & 1.47cde & $247.7 b$ & 353.1ef & $3.35 g$ \\
\hline CS 010 & Light green & $\begin{array}{l}\text { Light } \\
\text { green }\end{array}$ & 1 & 35.20cd & 13.36bcd & $5.00 \mathrm{c}$ & $1.28 \mathrm{e}$ & $426.7 \mathrm{a}$ & 467.0cd & 4.43e \\
\hline CS 011 & Light violet & Green & 1 & $36.00 \mathrm{c}$ & 13.43bcd & $5.10 \mathrm{c}$ & $1.81 \mathrm{c}$ & 312.0ab & 429.0de & $4.14 \mathrm{ef}$ \\
\hline CS 012 & Light violet & $\begin{array}{l}\text { Light } \\
\text { green }\end{array}$ & 1 & $36.00 \mathrm{c}$ & 14.13bcd & $5.65 b c$ & $1.73 \mathrm{~cd}$ & $289.3 b$ & 422.3de & $4.01 \mathrm{ef}$ \\
\hline CS 013 & Light green & $\begin{array}{l}\text { Light } \\
\text { green }\end{array}$ & 1 & $36.00 \mathrm{c}$ & $12.08 \mathrm{bcd}$ & $4.85 c$ & 1.44cde & $330.0 \mathrm{ab}$ & 467.8cd & $4.44 \mathrm{e}$ \\
\hline CS 014 & Light green & Green & 1 & 35.00cde & $12.04 \mathrm{bcd}$ & $5.20 \mathrm{c}$ & $1.28 \mathrm{c}$ & $214.3 \mathrm{~b}$ & $277.4 \mathrm{f}$ & $2.77 \mathrm{~h}$ \\
\hline CV (\%) & & & & 3.44 & 9.73 & 9.47 & 8.91 & 12.05 & 7.39 & 7.51 \\
\hline
\end{tabular}

Means showing different letters in a column differed significantly at $5 \%$ level by DMRT.

Note: 1 = Strong, 2 = Moderate, 3 = Mild 
The number of days required for green plant harvest ranged from 33.67 to 55.33 days and differed significantly (Table 1). The genotype CS003 took the maximum time for green plant harvest (55.33 days) followed by the genotypes CS001 and CS002 (46.00 days). Green plant harvesting time was earlier in genotype CS004 (33.67 days) which was followed by CS005, CS006, CS007, CS008, CS009, CS010, CS011, CS012, CS013 and CS014. These results have been supported by the results of Weiss (2002), Oliveira et al. (2003), Dhanasekar et al. (2000) and Badguzar et al. (1987). They reported plants for leaf purpose were harvested after 35-60 days after sowing (DAS). Plant height ranged from 11.25 to $18.96 \mathrm{~cm}$ and slightly differed among genotypes (Table 1). The highest plant height $(18.96 \mathrm{~cm})$ was found from the genotype CS003 followed by CS001 $(15.94 \mathrm{~cm})$, CS002 $(15.36 \mathrm{~cm})$ and CS008 $(15.26 \mathrm{~cm})$ but the lowest plant height was found in CSO05 $(11.25 \mathrm{~cm})$.

Number of leaves per plant slightly varied among the genotypes (Table 1). The maximum number of leaves was obtained from CS003 (8.10/plant) and the minimum was recorded in CS013 (4.85/plant). The intermediate number of leaves was noticed in CS001 (6.70/plant) and CS002 (6.35/plant) where they were statistically similar. All the genotypes except CS001, CS002 and CS03 produced identical number of leaves per plant. The number of leaves in green plant stage (4.5-5.00/plant) reported by Rahman (2000) was less than that of the present experimental.

Single plant weight ranged from 1.21 to $3.81 \mathrm{~g}$ (Table 1). Significantly maximum single plant weight was found in CS003 (3.81g) followed by CS001 (2.22g) and CS002 (2.39g) where CS001 and CS002 were identical. The moderate single plant weight was observed in CS007 (1.82g) and CS008 (1.80g) with no significant difference between them. The lowest single plant weight was noticed in CS004, which was at par with CS005, CS006, CS009, CS010 and CS014. Rahman (2000) reported 2.84-5.35 g single plant weight using 30 x 20 $\mathrm{cm}$ spacing whereas continuous sowing in $20 \mathrm{~cm}$ rows apart was used in the present experiment. For this reason single plant weight was lower in the present experiment.

The number of plants per square meter varied from 214.3 to 426.7 across the genotypes (Table 1). The maximum number of plants was harvested from the genotype CS003 $\left(426.7 / \mathrm{m}^{2}\right)$ but the lowest in CS014 $\left(214.3 / \mathrm{m}^{2}\right)$. Green plant weight per square meter ranged from $275.1 \mathrm{~g}$ to $972.2 \mathrm{~g}$ and differed significantly among the different genotypes (Table 1). Significantly the maximum weight of green plant was obtained from CS003 $\left(972.2 \mathrm{~g} / \mathrm{m}^{2}\right)$ and the minimum in CS004 $\left(275.1 \mathrm{~g} / \mathrm{m}^{2}\right)$ which was statistically similar to CS005 and CS009. The second highest weight of green plants was found in CS001 $\left(656.9 \mathrm{~g} / \mathrm{m}^{2}\right)$ and CS002 $\left(670.3 \mathrm{~g} / \mathrm{m}^{2}\right)$ with no significant difference between them. The genotype CS008 gave reasonable weight of green plants $\left(515.8 \mathrm{~g} / \mathrm{m}^{2}\right)$ closely followed by the 
genotypes CS007, CS010, CS011, CS012 and CS013. Maximum weight of green plants was found in CS003 contributed by maximum days to plant harvest (55.33 days), the highest plant height, leaves/plant and single plant weight. Green plant weight of 114.6 to $213.6 \mathrm{~g} / \mathrm{m}^{2}$ and $371.8-854.8 \mathrm{~g} / \mathrm{m}^{2}$ was reported by Rahman (2000) and Badguzar et al. (1987), respectively.

Fourteen genotypes exhibited significant variation of foliage yield (Table 1). The highest foliage yield was recorded from the genotype CS003 (9.85 t/ha) followed by CS002 (6.69 t/ha) and CS 001 (6.47 t/ha) while the lowest from the genotype CS004 (2.75 t/ha). Foliage yield was not significantly different between CS001 and CS002. The lowest foliage yield was observed in the genotype, CS004 (2.75 t/ha) that was at par with CS014 and CS005. The genotype CS008 produced good foliage yield (5.08 t/ha) which was statistically similar to CS007. The variation in foliage yield was due to the variation of genetic inheritance. Leaf yield of $10.00 \mathrm{t} / \mathrm{ha}$ (Co. 2) was reported by Mohideen et al. (1984). Leaf yield of USA cultivar 'Sunbless' and local cultivar (13 and $8 \mathrm{t} / \mathrm{ha}$, respectively) harvested in winter after 6-7 weeks of seed sowing was reported by Chow et al. (1984). On the basis of foliage yield performance the genotypes CS001, CS002 and CS003, and based on yield and aroma CS008 genotypes were suitable.

\section{References}

Anonymous. 2001. Annual Report for 2000-2001. Spices Research Centre, Shibganj, Bogra. p. 37.

Badguzar, C. D., K. E. Lawande, P. N. Kale and K. G. Choudhuri. 1987. Response of coriander to to foliar application of urea. Current Res. Rep. 3 (2): 118-119.

Chow, L., K. F. Winter, M. A. Busawon and I. Rajkomar. 1984. Foliage yield and bolting in coriander at different times of harvest. Tech. Bull. Ministry of Agric. Mauritius 4: 24-27.

Dhanasekar, D., M. Vijayakumar, V. A. Sathiyamurthy and V. Sankar. 2000. Studies on growth pattern in coriander to fix the optimum stage of harvest for green yield. South Indian Hort. 48(1-6): 157-159

Ghafoor, A., A. Sharif, Z. Ahmad, M. A. Zahid and M. A. Rabbani. 2001. Genetic Diversity in Blackgram (Vigna mungo L. Hepper). Field Crops Res. 69: 183-190.

Islam et al. 2004. Edited. Krishi projukti Hatboi (Handbook on Agro-technology), $3^{\text {rd }}$ ed. Bangladesh Agricultural Reseach Institute, Gazipur 1701, Bangladesh. P. 386.

Janardhanan, M. and J. E. Thoppil. 2004. Herb and Spice Essential Oils. Discovery Publishing House, New Delhi-110002. Pp. 40-42.

Mohideen, M. S., J. B. M. Abdul Khader and S. Muthuswami. 1984. Coriander- A crop of good prospets for Tamil Nadu. Indian Cocoa, Arecanut and Spices J. 8 (1): 5-6.

Rahman, M. A. 2000. Morphological characters and yield potential of different coriander genotypes. MS Thesis. Dept. of Hort. Bangabandhu Sheikh Mujibur Rahman Agricultural University (BSMRAU), Gazipur. 53 P. 
Singhania, D.L., D. Singh and R. S. Raje. 2006. Coriader. In: Ravindran, P. R., K. N. Babu, K. N. Shiva. and J. A. Kallupurackal (eds.). Advances in Spices and Achievments of Spices Research in India since Independence. Pp. 678-695. Agrobios (India), Agro House, Behind Nasrani Cinema. Chopasani Road. Jodhpur 342002.

Tiwary, R. S. and A. Agarwal. 2004. Production Technology of Spices. $1^{\text {st }}$ ed. International Book Distribution Co. Chaman Studio Building, $2^{\text {nd }}$ floor, Charbagh, Lucknow, 2260004 U. P., India. Pp. 254-271.

Weiss, E. A. 2002. Spice Crops. CABI Publishing, CAB International, Wallingfoard, Oxon, OX10 8DE, U. K. Pp. 243-261. 